\title{
Effect of water de-stratification on dissolved oxygen and ammonia in tilapia ponds in Northern Thailand
}

\author{
Patcharawalai Sriyasak (i) Chanagun Chitmanat - Niwooti Whangchai • \\ Jongkon Promya $\cdot$ Louis Lebel
}

Received: 29 May 2015/ Accepted: 5 September 2015/Published online: 24 September 2015

(C) The Author(s) 2015. This article is published with open access at Springerlink.com

\begin{abstract}
Episodes of low concentrations of dissolved oxygen and high concentrations of ammonia are major causes of fish stress, which in turn, reduces growth and increases mortality rates in aquaculture ponds. This study measured the effects of water de-stratification on dissolved oxygen and ammonia concentrations in tilapia ponds in Northern Thailand. Fifteen ponds in five provinces in Northern Thailand were sampled on multiple dates in the hot, wet, and dry seasons. Thermal water stratification peaked around 14:00-16:00 h each day; wherein the differences between surface and lower water temperatures in the $0.8-2.0 \mathrm{~m}$ deep ponds reached $1.3-4.0^{\circ} \mathrm{C}$. Thermal de-stratification in the hot season and dry season usually occurred late at night; in the wet season however, it occurred early in the evening due to the cooling effects of rain. The mixing of surface and bottom waters decreased dissolved oxygen levels in water near the surface, and, increased concentration levels in the bottom water layer. Mean DO concentrations of integrated and commercial ponds were lower than $1 \mathrm{mg} / \mathrm{L}$ from 02:00 to $06: 00 \mathrm{~h}$, in $68 \%$ of the observations. Repeated measures ANOVA analysis showed that water depth and fish culture systems have significant effects on total ammonia nitrogen (TAN). TAN concentrations near the surface were lower than at the bottom, and increased after water destratification. TAN in the integrated culture system was significantly higher than in commercial and subsistence systems. Toxic, un-ionized ammonia $\left(\mathrm{NH}_{3}\right)$ concentrations in all culture systems, however, were still lower than standard toxicity level for tilapia. The improved understanding of the seasonal and culture-system specific effects of de-stratification on pond water quality provided by this study, are useful for improving pond management practices to reduce the risks of exceeding DO thresholds. In particular, fish farmers should: (1) take care to avoid over-feeding and manage water and sediments to prevent excessive accumulation of organic matter and waste at the bottom of ponds, which can influence other water quality parameters; and, (2) use aeration and mechanical mixing interventions at critical times to reduce stress on fish from low DO concentrations, and thus avoid risks of mass mortality events.
\end{abstract}

Keywords Thermal de-stratification $\cdot$ Dissolved oxygen $\cdot$ Ammonia $\cdot$ Fish culture

P. Sriyasak $\cdot$ C. Chitmanat $\cdot$ N. Whangchai $\cdot$ J. Promya

Faculty of Fisheries Technology and Aquatic Resources, Maejo University, Chiang Mai, Thailand

P. Sriyasak $(\bowtie) \cdot$ L. Lebel

Unit for Social and Environmental Research, Chiang Mai University, Chiang Mai, Thailand

e-mail: kpatchara@hotmail.com 


\section{Introduction}

Nile tilapia culture in earthen ponds in Thailand is expanding: between 2003 and 2013 culture area and production increased by 12 and $46 \%$, respectively (DOF 2013). This is due to high consumer demand, improvements in seed production, including, the introduction of sex-reversal technologies (Bhujel 2013), and the availability of pellet feeds; thus allowing producers to achieve high fish growth rates and yields (AbdelTawwab 2012; Bhujel 2013). At the same time, fish farmers are facing increasing problems of maintaining adequate water quality in fish ponds (Sriyasak et al. 2014).

Water quality in a pond influences feeding, growth, disease burdens, and survival rates (Chainark and Boyd 2010; Pandit and Nakamura 2010). Water quality is controlled by a complex interplay of many factors, including weather conditions (Ahmed et al. 2011). For example, dissolved oxygen (DO) is related to phytoplankton production and respiration (Smith and Piedrahita 1988); nitrogen waste such as ammonia is related to the amount of organic matter inputs and ammonium excretion by fish (Gross et al. 1999; Hargreaves 1998); and, water temperature and thermal stratification are controlled by sunlight and air temperature (Egna and Boyd 1997; Losordo and Piedrahita 1991).

Adequate DO concentrations in a fish pond are essential for maintaining optimal growth (Chang and Ouyang 1988). Ponds with high nutrient input have high phytoplankton concentrations, and as a consequence, have high DO concentrations in the afternoon due to phytoplankton photosynthesis (Diana et al. 1991), and low DO concentrations in the early morning due to phytoplankton, water column, and sediment respiration (Chang 1989). Oxygen concentrations lower than $3 \mathrm{mg} / \mathrm{L}$ reduce feed intake and growth in Nile tilapia (Duy et al. 2008).

Ammonia is the first form of nitrogen released when organic matter decomposes, and can exist in two forms: un-ionized ammonia $\left(\mathrm{NH}_{3}\right)$ or ionized ammonia $\left(\mathrm{NH}_{4}{ }^{+}\right)$(Durborow et al. 1992; Gandhi 2012; Gross et al. 1999). Un-ionized ammonia $\left(\mathrm{NH}_{3}\right)$ is toxic to fish, and becomes even more toxic as water temperature and $\mathrm{pH}$ increase (EPA 2013; Hargreaves and Tucker 2004). Acute toxicity of ammonia is due to its effect on the central nervous system (Randall and Tsui 2002); ammonia concentrations of $7.40 \mathrm{mg} / \mathrm{L}$ have been shown to cause mass mortality in tilapia fingerling within $24 \mathrm{~h}$ (Benli and Koksal 2005). Fish exposed to toxic levels of ammonia cannot excrete ammonia efficiently; as a result, ammonia levels in blood and tissues increase along with $\mathrm{pH}$ levels, therefore affecting enzyme activity (Lawson 1995). This can lead to poor feed conversion, slower growth rates, and reduced resistance to diseases (Gandhi 2012; Hargreaves and Tucker 2004).

Shallow aquaculture ponds undergo diel cycles of thermal and chemical vertical stratification (Losordo and Piedrahita 1991). Stratification of water in ponds arises due to the differences in water density, as the absorption of solar radiation decreases with increasing depth of the water column (Chowdhury et al. 2014; Klimaszyk and Tomaz 2007; Losordo and Piedrahita 1991). Warm surface water also has higher DO levels from photosynthesis, while cooler bottom water has lower DO, plus accumulated nitrogenous waste from uneaten feed and feces that drop down to the sediment (Gandhi 2012). De-stratification, or the remixing of water, occurs as air temperature drops and the surface layer cools down, therefore becoming denser than water in the lower layers. The surface water then sinks and forces water at the bottom to rise, thus turning over the layers (Chowdhury et al. 2014; Szyper and Lin 1990). After water mixing, DO in the surface layer falls, and the concentration of nitrogenous waste like ammonia increases. Stratification with depth in ponds, followed by rapid turnover or exchange of surface and bottom water layers, can expose fish to dangerously low dissolved oxygen levels, even near the surface. Conversely, mixing helps to increase oxygen levels near the bottom.

For Nile tilapia cultured in earthen ponds in Thailand, tilapia mortality from disease outbreak frequently occurs when DO levels are low and ammonia concentrations are high (Chitmanat 2013). Fish culture in pellet feed based and poultry or livestock integrated systems appear to be more impacted by periods of prolonged cloud cover and heavy rain than subsistence culture system (Pimolrat et al. 2013). Fish in ponds that are exposed to hot weather for several days, and then treated to a sudden period of heavy rain or cloud cover, also tend to be vulnerable to diseases due to low oxygen condition and high organic wastes (Srisapoome and Areechon 2014); this is because rain encourages water mixing between the surface and bottom layers.

Stratification and water turnover is known to occur in tilapia fish ponds in Northern Thailand (Sriyasak et al. 2013). The objective of this study was to measure the effect of water de-stratification on concentrations of DO and ammonia in fish ponds that are managed under different culture systems during different seasons in Northern Thailand. As tilapias are known to be sensitive to episodes of low concentrations of DO and high 
concentrations of ammonia, a better understanding of the effects of de-stratification on pond water quality should be useful for managing water- and climate-related risks to aquaculture production.

\section{Methods}

Study site

This study made observations and measurements in 15 tilapia earthen ponds located in five provinces in Northern Thailand: Chiangrai, Chiangmai, Phayao, Lampang, and Nakhon Sawan (Fig. 1). Pond sizes ranged

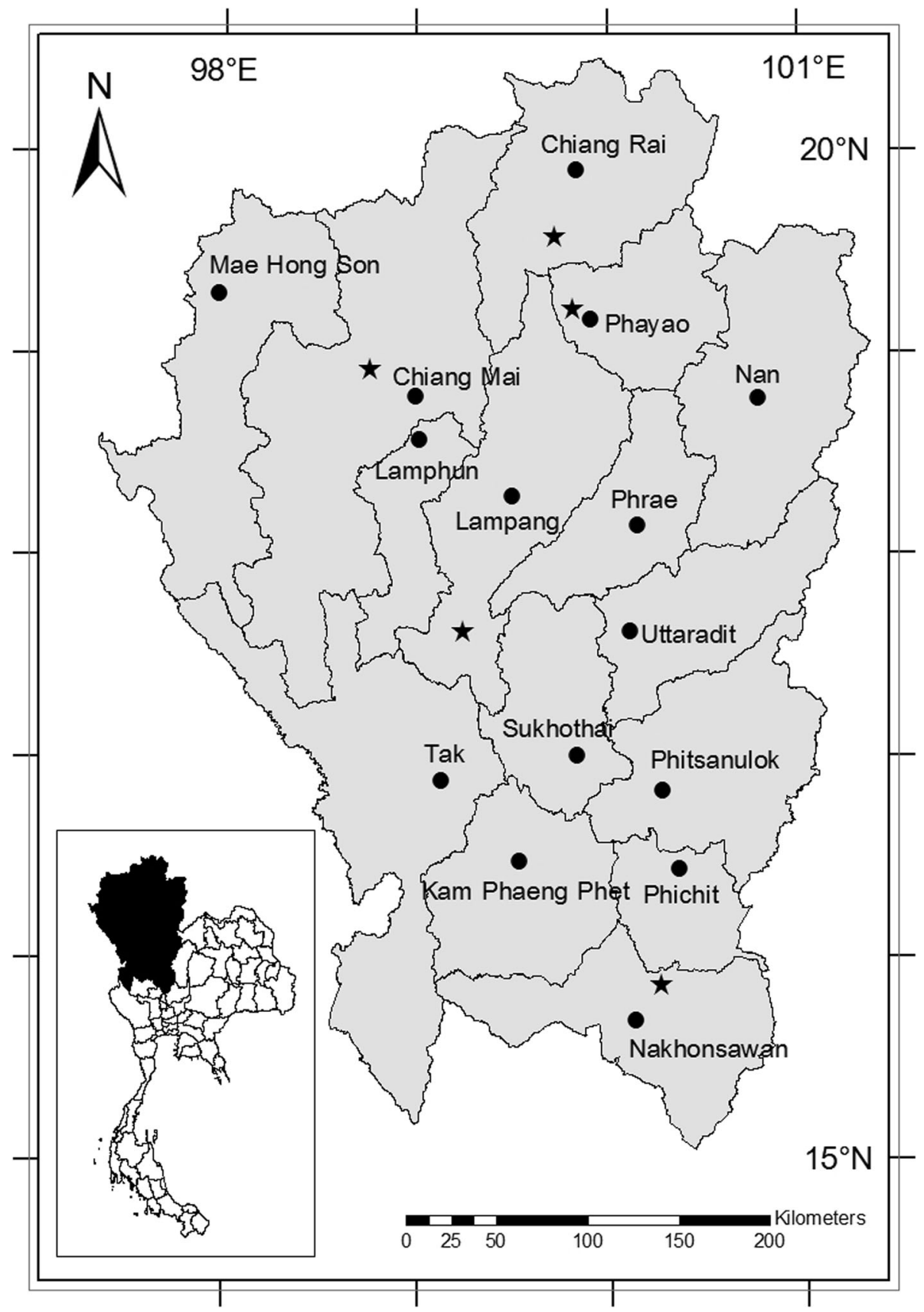

Fig. 1 Map of study area in Northern Thailand. Stars indicate farm locations, dots the city district in each province 
Table 1 Major features of ponds managed under different culture systems that were monitored in the study

\begin{tabular}{llll}
\hline Pond feature & Culture system & \\
\cline { 2 - 4 } & Integrated & Commercial & Subsistence \\
\hline Number of ponds & 3 & 6 & 6 \\
Pond area $\left(\mathrm{m}^{2}\right)$ & $2600 \pm 1830$ & $3400 \pm 1050$ & $460 \pm 340$ \\
Pond depth $(\mathrm{m})$ & $1.2 \pm 0.4$ & $1.2 \pm 0.1$ & $1.0 \pm 0.2$ \\
Stocking rate $\left(\mathrm{fish} / \mathrm{m}^{2}\right)$ & $2.7 \pm 0.5$ & $2.8 \pm 0.4$ & $0.8 \pm 0.3$ \\
Culture period (months) & $5.8 \pm 0.7$ & $6.5 \pm 0.5$ & $14.0 \pm 3.1$ \\
Feed type & Pellet feed & Pellet feed & Pellet feed, vegetable waste and food scarps \\
Manure inputs & Yes & No & No \\
Water renewal rate & Seldom & $10 \%$ per day & Seldom \\
Production & All harvest sold & All harvest sold & Harvest consumed and sold
\end{tabular}

Mean \pm SD

from 0.16 to 0.64 ha, with depths of $0.8-2.0 \mathrm{~m}$. Ponds were grouped according to culture system: commercial (where prepared pellet feed was regularly provided and crops tended to be harvested once); integrated (where fish and livestock were raised in the same area and the wastes from the latter were dumped into ponds); and subsistence (where feeding was sporadic and fish were harvested continuously for consumption and market). The characteristics of each culture system are summarized in Table 1.

Water parameters

Altogether, 660 samples of fish pond water were collected for water quality analysis (15 ponds $\times 11$ months $\times 4$ samples) between May 2013 and 2014. Samples were classified into three seasons for analysis: the "dry" season (November-February) when air temperatures and precipitation are lowest; the pre-monsoon "hot" season (March-May) when temperatures are highest; and the monsoon "wet" season (June-October) when precipitation is highest (Thai Meteorological Department 2012). Ambient air temperature, water temperature, $\mathrm{pH}$, turbidity and $\mathrm{DO}$ were monitored at $2 \mathrm{~h}$ intervals, over a $24 \mathrm{~h}$ period, in each season, at every $20 \mathrm{~cm}$ depth, with a multimeter (TOA DKK WQC-22A model, Japan). Moreover, water samples were collected $20 \mathrm{~cm}$ below the surface and $20 \mathrm{~cm}$ above the pond bottom during stratified and de-stratified conditions. Chemical analyses were carried out for total ammonia-nitrogen (TAN) and chlorophyll-a according to standard methods (APHA 1980).

Toxic un-ionized ammonia $\left(\mathrm{NH}_{3}\right)$ concentration was calculated from the equation:

$$
\mathrm{NH}_{3}=(a) \mathrm{TAN}
$$

where, $(a)$ is the mole fraction of un-ionized ammonia in aqueous solution at different $\mathrm{pH}$ values and temperatures (Emerson et al. 1975).

The maximum difference between surface and bottom temperatures of the pond was used as an indicator of stratification (Stefan et al. 1996). The de-stratification time was defined as when there was no detectable difference (less than $0.1{ }^{\circ} \mathrm{C}$ ) between surface and bottom water temperatures. Data on precipitation were taken from the nearest weather station to each farm (Thai Meteorological Department 2014).

\section{Statistical analysis}

A factor analysis using principal component analysis (PCA) with a varimax rotation was first carried out to help understand the patterns of co-variation among the many water quality variables. Separate ANOVA models were then used to analyze the combined effects of culture system, season, and sampling depth factors on maximum water temperature stratification, minimum DO, DO stratification, and mean TAN. TAN values were log-transformed prior to analysis to homogenize variances, and then analyzed using repeated measures ANOVA for concentrations before and after stratification. Pond depth $(<1$ and $>1 \mathrm{~m})$ was included as a 
separate predictor as it could potentially influence thermal stratification; but as it was later found not to be significant it was thus excluded from the final models.

\section{Results}

Principal component analysis

Logically related individual water quality measures were strongly correlated with the same factor (Table 2). Thus, temperature variables covaried and all loaded on Factor 1, whereas TAN variables were correlated with Factor 3, and DO variables with Factor 4. Factor 2 could be interpreted as high plankton and organic input conditions, as both chlorophyll-a and turbidity variables were positively correlated with the factor, while $\mathrm{pH}$ was negatively correlated. Based on the clear separation of outcome variables of interest in this exploratory analysis, it seems justified to proceed to analyzing the effects of season, culture system, and sampling depth on the selected temperature, DO and TAN variables separately.

Weather, water stratification and de-stratification in fish ponds

Averaged over $24 \mathrm{~h}$, air temperatures, as well as surface and bottom water temperatures, at pond sites on sampling dates, were significantly lower in the dry season than in the hot or wet seasons as expected (Table 3). Maximum water surface temperature usually occurred at 16:00 h, and minimum at 06:00 h. The highest water temperature observed was $38.0{ }^{\circ} \mathrm{C}$ in the hot season, and the lowest was $18.3{ }^{\circ} \mathrm{C}$ during the dry season. Daily air temperature range was lower in the wet season than in the other two seasons. Average mean precipitation also varied among seasons as expected (Table 3).

The maximum difference between surface and bottom water temperatures always occurred in measurements made in the afternoon, and ranged between 0 and $7.1^{\circ} \mathrm{C}$. The degree of stratification varied among seasons and culture systems with a significant interaction between the two factors $(P<0.05$, Fig. 2). In the wet season, culture systems behaved alike, whereas in the hot and dry seasons, integrated ponds showed relatively larger thermal stratification (Fig. 2).

Stratification usually began from 14:00 to 16:00 h, and became less apparent during the night, as the upper layer cooled and water began to mix. Thermal de-stratification in the wet season occurred between 18:00 and 22:00 h; in the dry season between 20:00 and 24:00 h; and in the hot season it occurred between 22:00 and 04:00 h. Water de-stratification in the wet season in all culture system types occurred earlier than in the dry and hot seasons; possibly because cold water from rain decreased surface water temperature, in turn,

Table 2 Factor loading, eigenvalues, and percentage of variance from the principal component analysis

\begin{tabular}{|c|c|c|c|c|}
\hline Variables & Factor 1 & Factor 2 & Factor 3 & Factor 4 \\
\hline Air temperature & 0.91 & 0.12 & & -0.15 \\
\hline Surface water temperature & 0.97 & 0.13 & & \\
\hline Bottom water temperature & 0.92 & & 0.18 & \\
\hline DO surface & & 0.22 & & 0.83 \\
\hline DO bottom & -0.19 & -0.36 & & 0.73 \\
\hline TAN before stratification & & & 0.96 & \\
\hline TAN after stratification & & 0.21 & 0.92 & \\
\hline $\mathrm{pH}$ & & -0.72 & -0.17 & 0.43 \\
\hline Turbidity & & 0.88 & & 0.14 \\
\hline Chlorophyll-a & 0.20 & 0.85 & 0.14 & \\
\hline Eigenvalue & 3.54 & 2.00 & 1.46 & 1.34 \\
\hline Percentage of variance & 35.4 & 20.0 & 14.6 & 13.4 \\
\hline Cumulative (\%) & 35.4 & 55.3 & 70.0 & 83.4 \\
\hline
\end{tabular}

Values larger than 0.7 are in bold 
Table 3 Air and water temperatures as well as daily precipitation (Mean \pm SD) at fish ponds in three different seasons; different superscript letters in the same rows indicate a significant difference between means at $P<0.05$ (Tukey's HSD)

\begin{tabular}{llcl}
\hline Variables & \multicolumn{3}{l}{ Season } \\
\cline { 2 - 4 } & Hot (March-May) & Wet (June-October) & Dry (November-February) \\
\hline Mean maximum air temperature $\left({ }^{\circ} \mathrm{C}\right)$ & $34.3 \pm 6.9^{\mathrm{a}}$ & $30.5 \pm 8.8^{\mathrm{b}}$ & $30.8 \pm 6.6^{\mathrm{b}}$ \\
Daily air temperature range $\left({ }^{\circ} \mathrm{C}\right)$ & $12.5 \pm 3.7^{\mathrm{a}}$ & $8.1 \pm 2.8^{\mathrm{b}}$ & $14.4 \pm 4.2^{\mathrm{a}}$ \\
Air temperature $\left({ }^{\circ} \mathrm{C}\right)$ & $28.2 \pm 2.9^{\mathrm{a}}$ & $27.7 \pm 2.7^{\mathrm{a}}$ & $22.8 \pm 3.9^{\mathrm{b}}$ \\
Surface water temperature $\left({ }^{\circ} \mathrm{C}\right)$ & $29.6 \pm 2.6^{\mathrm{a}}$ & $28.7 \pm 2.3^{\mathrm{a}}$ & $24.2 \pm 3.4^{\mathrm{b}}$ \\
Bottom water temperature $\left({ }^{\circ} \mathrm{C}\right)$ & $29.1 \pm 2.7^{\mathrm{a}}$ & $28.3 \pm 2.1^{\mathrm{a}}$ & $23.7 \pm 3.4^{\mathrm{b}}$ \\
Daily precipitation $(\mathrm{mm} /$ day) & $2.9 \pm 1.7^{\mathrm{b}}$ & $6.5 \pm 2.2^{\mathrm{a}}$ & $0.8 \pm 1.0^{\mathrm{c}}$ \\
\hline
\end{tabular}

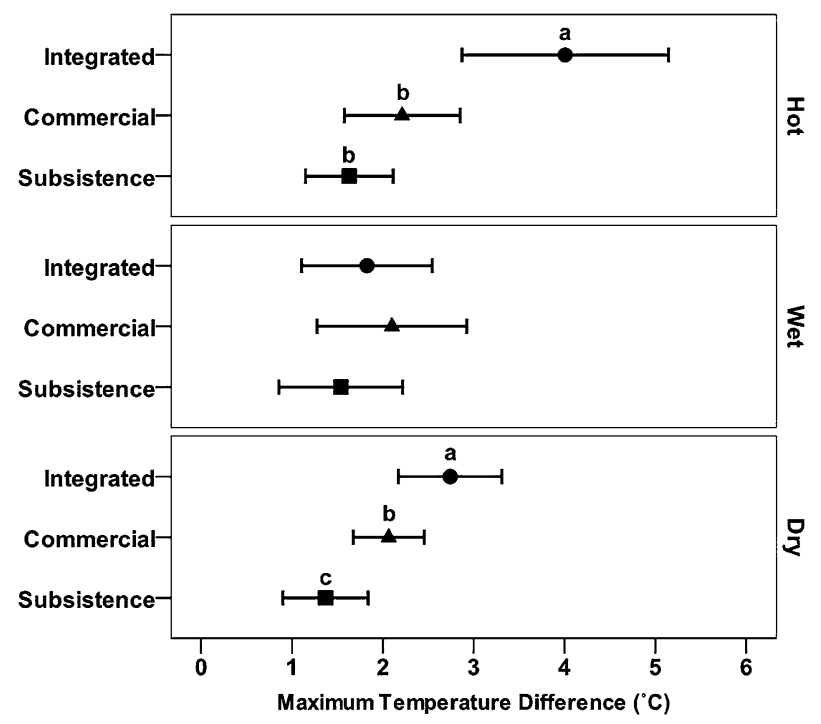

Fig. 2 Maximum difference between surface and bottom water temperatures in different culture systems and seasons. Plotted symbols are means and bars $95 \%$ confidence intervals (CI) for those means

encouraging de-stratification. To support this argument, Fig. 3 shows the thermal stratification on three separate observation days, one of which happen to rain heavily at about 16:00 h (Fig. 3c); 2 h later, complete stratification could be observed (Fig. 3c), two or more hours earlier than usual. Thermal stratification was sometimes substantial (Fig. 3b), and at other times less so (Fig. 3a).

In a few instances however, no stratification was observed: 11 occasions in the dry season, 7 occasions in the hot season, and 4 occasions in the wet season. The reasons for these instances include: heavy rain during the day $(n=6)$; high cloud cover $(n=8)$; exchanging of pond water $(n=4)$; and the use of aerators $(n=4)$. These events were too rare for powerful statistical comparisons to be made.

Effect of water de-stratification on dissolved oxygen in fish ponds

Thermal stratification in ponds (Fig. 3) was accompanied by DO stratification (Fig. 4). The highest DO was found in the surface water layer during the afternoon, which began to decrease after sunset. The maximum DO recorded at the surface layer in the afternoon was $22.7 \mathrm{mg} / \mathrm{L}$; this was in an integrated pond system in May. Oxygen oversaturation in the late afternoon was found to occur in both integrated and commercial ponds. On the other hand, under-saturation of oxygen in the late afternoon was observed in some subsistence ponds.

These differences in extremes among culture systems are consistent with measures of chlorophyll-a and turbidity. The mean chlorophyll-a concentration of integrated ponds $(551 \pm 300 \mu \mathrm{g} / \mathrm{L})$ was significantly higher than commercial ponds $(227 \pm 208 \mu \mathrm{g} / \mathrm{L})$ or subsistence ponds $(36 \pm 42 \mu \mathrm{g} / \mathrm{L})$. Likewise, the 


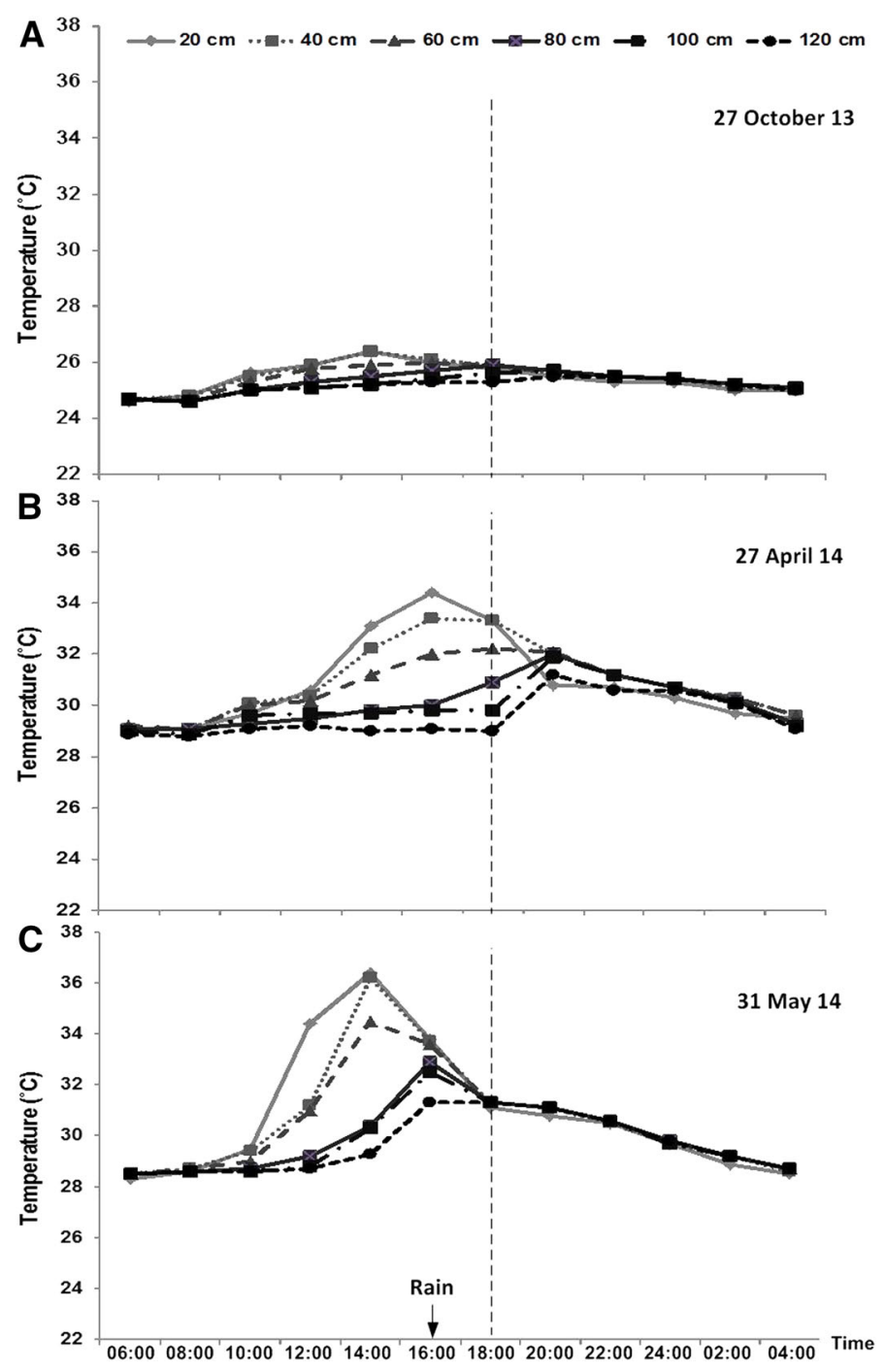

Fig. 3 Thermal stratification of pond waters on three illustrative dates with small maximum temperature difference (a); large maximum temperature difference (b); and large temperature difference and heavy afternoon rainfall (c)

turbidity in integrated ponds $(153 \pm 82 \mathrm{NTU})$ was significantly higher than commercial ponds $(88 \pm 52$ NTU) or subsistence ponds ( $36 \pm 26 \mathrm{NTU})$.

Water de-stratification resulted in decreased DO concentration at the surface, and increased DO at the bottom of the pond (Fig. 4). Mean DO concentration of integrated and commercial ponds were lower than $1 \mathrm{mg} / \mathrm{L}$, from 02:00 to $06: 00 \mathrm{~h}$, in $68 \%$ of observations; whereas the subsistence systems were always over $1 \mathrm{mg} / \mathrm{L}$ during the same periods.

ANOVA was used to analyze the influence season and culture system had on average minimum DO concentrations over a 24-h period. Average minimum DO concentration was low in integrated ponds, and was especially lower than the other two culture systems during the dry season (Fig. 5). Average 24-h DO concentrations were lower at the bottom of the pond $(2.8 \pm 2.3 \mathrm{mg} / \mathrm{L})$ than at the surface $(5.6 \pm 2.3 \mathrm{mg} / \mathrm{L}$, $P<0.001)$. Average $24-\mathrm{h}$ DO concentrations were higher in integrated $(6.5 \pm 6.0 \mathrm{mg} / \mathrm{L})$ and commercial ponds $(6.1 \pm 4.5 \mathrm{mg} / \mathrm{L})$, than in subsistence ponds $(4.6 \pm 3.2 \mathrm{mg} / \mathrm{L}, P<0.05)$.

Mean maximum DO difference between top and bottom water layers varied significantly among culture systems, but was unaffected by season (Fig. 6). Integrated culture system showed the greatest DO stratification, whereas subsistence system showed the least (Fig. 6). 


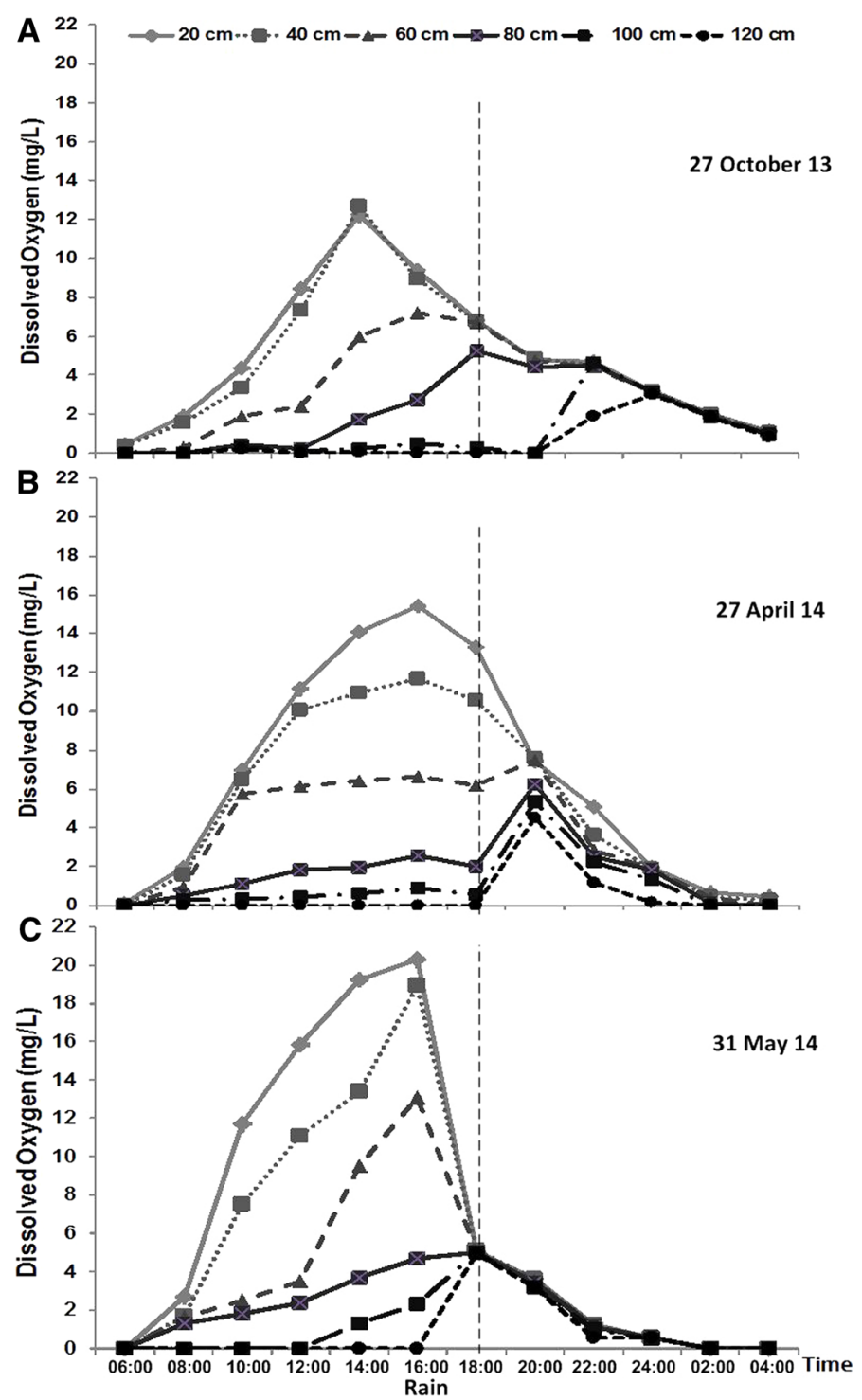

Fig. 4 Diel stratification of dissolved oxygen of pond waters on three illustrative dates (as in Fig. 3) with small maximum temperature difference (a); large maximum temperature difference (b); and large temperature difference and heavy afternoon rainfall (c)

Effect of water de-stratification on total ammonia in fish ponds

Repeated measures, multi-factor ANOVA was used to analyze the influence of depth of water (surface and bottom), season, and fish culture system, on TAN before and after de-stratification. The analysis showed that fish culture systems and depth of pond had significant effects on TAN (Fig. 7). TAN concentrations in tilapia ponds at the surface were lower than at the bottom of the pond $(P<0.05)$. After de-stratification, TAN at the surface water layer clearly increased (Fig. 7). Water de-stratification resulted in increased TAN at the surface layer. TAN of the integrated system was significantly higher than in commercial and subsistence systems (Tukey's HSD, $P<0.05)$. However, season had no significant effects on TAN $(P>0.2)$. The average levels of un-ionized ammonia $\left(\mathrm{NH}_{3}\right)$ concentration of integrated and commercial pond systems were $0.012 \pm 0.01 \mathrm{mg} / \mathrm{L}$, whilst in subsistence system it was $0.005 \pm 0.01 \mathrm{mg} / \mathrm{L}$. 


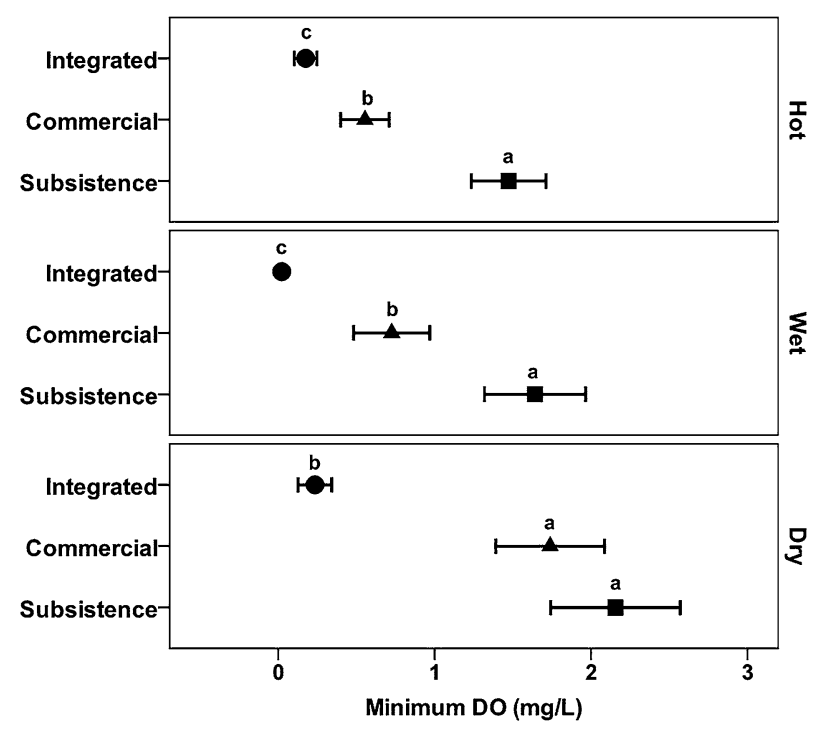

Fig. 5 Minimum DO concentration in different culture systems and seasons. Plotted symbols are means and bars $95 \%$ confidence intervals (CI) for those means

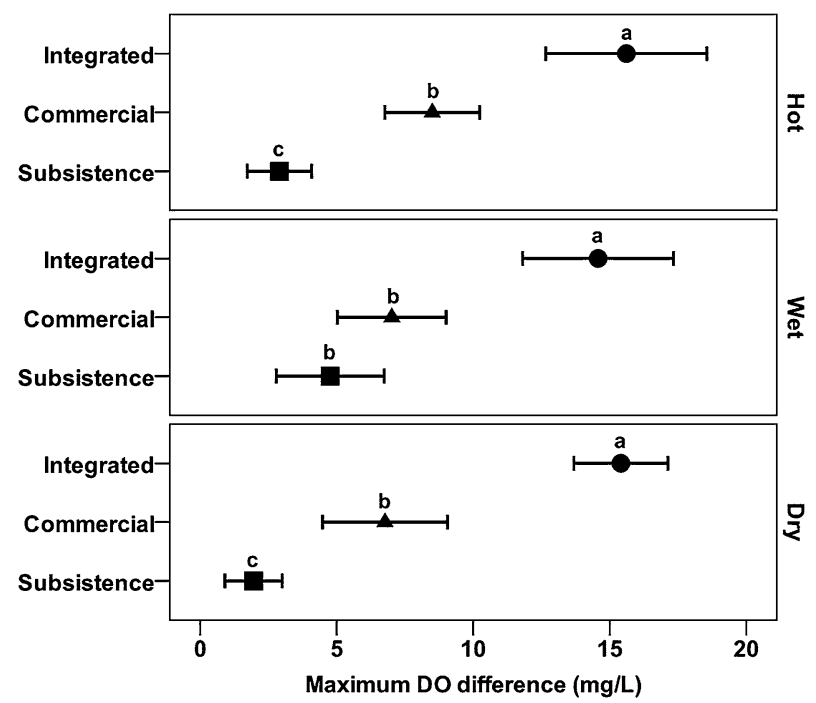

Fig. 6 Difference between surface and bottom DO concentrations in the afternoon in different culture systems and seasons. Plotted symbols are means and bars $95 \%$ confidence intervals (CI) for those means

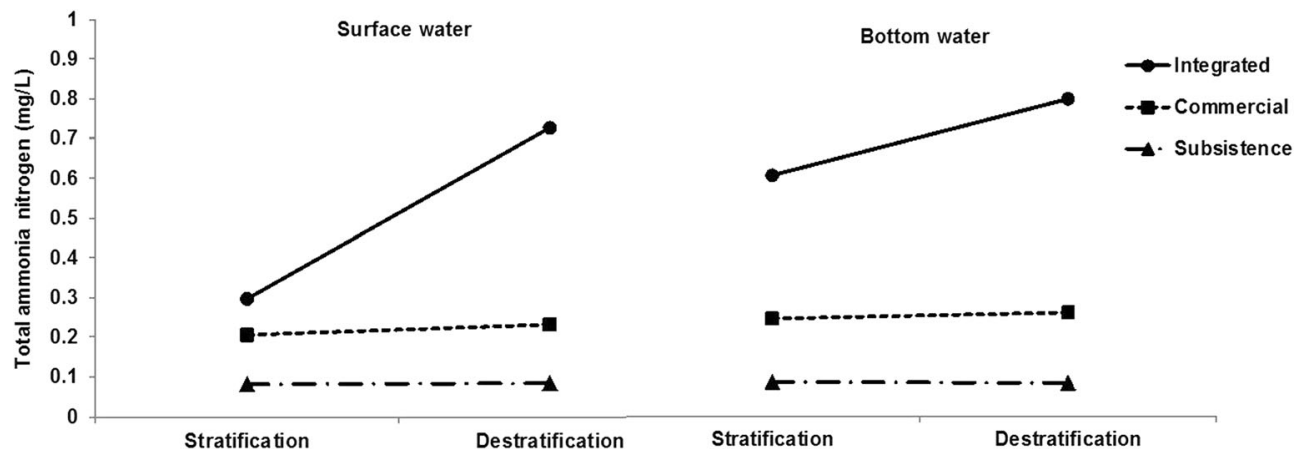

Fig. 7 Total ammonia nitrogen of different culture systems at surface and bottom pond before and after de-stratification 


\section{Discussion}

The largest differences in temperature between surface and bottom layer were observed in integrated ponds during the hot season; whereas differences in the dry season were modest and in the wet season largely absent (Fig. 2). Four factors help explain these finding. First, the high load of nutrient and fertilizer inputs in integrated ponds caused phytoplankton blooms (Little and Edwards 2004; Szyper and Lin 1990). In this study, concentrations of Chlorophyll-a and overall turbidity, were much higher in integrated ponds than the other two systems. Consequently, high biomass of plankton or suspended particles in the surface layer limits light penetration to the lower water layers (Litchman et al. 2004; Tadesse et al. 2004). Second, is that solar radiation in the hot season tends to be higher than in the other seasons of Thailand (Janjai and Wattan 2011). Factors one and two explain the high potential for thermal stratification to occur during the hot season. A third factor, is that the air temperature range within a 24-h period tended to be greater in the hot and dry seasons than in the wet season (Table 3), which, if wind-mixing was limited, would generate thermal gradients (Losordo and Piedrahita 1991). A fourth factor, is heavy day time rainfall in the wet season; which could help explain why thermal stratification sometimes does not occur in this season (Fig. 2).

Thermal stratification usually peaked in the afternoon and collapsed in the evening (Fig. 3). Water destratification in the wet season occurred earlier than in the dry and hot season, probably due to mixing effects from rain (Diana et al. 1991). Seasonal differences in typical wind conditions might also have played a role (Diana et al. 1991; Culberson and Piedrahita 1996). Thermal de-stratification effects DO concentrations; decreasing them in surface waters while increasing them in the bottom layers (Boyd et al. 1978; Chang 1989). Water mixing is an important factor to consider therefore, as it effects fish respiration. On the other hand, the increase of DO that occurs at the bottom water layers as a result of mixing may be significant to improving the aerobic conditions at the bottom of ponds (Chang and Ouyang 1988). The use of aerators or pond mixers to assist in water mixing during the afternoons can help to reduce stratification in fish ponds; in addition, introduce more oxygen that can be used during the night, when DO concentrations otherwise might reach critically low levels (Chowdhury et al. 2014; Szyper and Lin 1990).

Oxygen stratification had a similar diel pattern with thermal stratification. The highest DO level was found in surface water level in the afternoon, and decreased in the evening (Fig. 4). Photosynthetically active solar radiation (PAR) drives photosynthesis (Romaire and Boyd 1979). Therefore, DO concentration generally increases with increasing PAR in the morning (Tadesse et al. 2004). In the afternoon, DO concentrations continue to increase even after PAR decreases; this observation is consistent with previous studies that suggest there is a time lag in photosynthesis response to changes in light intensity (Cloot 1994; Szyper et al. 1992).

The degree of DO stratification varied significantly among culture systems: integrated culture systems showed the greatest DO stratification, and subsistence systems the least (Fig. 6). In integrated and commercial ponds, oxygen oversaturation occurred during the late afternoon, while the bottom layer was often depleted of any oxygen. A likely explanation is that high input nutrient ponds have much higher phytoplankton biomass than the lower input systems, and this is thus reflected in DO concentrations. The bottom layers had low photosynthesis activity due to the abundance of phytoplankton in the upper layers, which prevented light from penetrating into the deeper layers (Diehl 2002). Respiration by phytoplankton, settling detritus and the sediments may have also contributed to the depletion of oxygen in the bottom layers (Chang 1989; Hargreaves 1998).

In two-thirds of the early morning observations in integrated and commercial ponds, DO levels were lower than $1 \mathrm{mg} / \mathrm{L}$. The critical threshold value for respiration for Nile tilapia is a DO concentration of $0.8 \mathrm{mg} / \mathrm{L}$, at $26{ }^{\circ} \mathrm{C}$ (Duy et al. 2008). Be that as it may, tilapia can survive under DO concentrations of lower than $1 \mathrm{mg} / \mathrm{L}$, by drawing air directly from the atmosphere at the pond surface. Mortality can occur when DO concentrations become lower than $2 \mathrm{mg} / \mathrm{L}$ for more than 2-3 days consecutively (Chervinski 1982). On days with dense cloud cover, low light intensities affect the oxygen budget of a pond; as a result, the oxygen production and the oxygen reserve for use at night declines (Kepenyes and Varadi 1984). One commercial pond in Nakhon Sawan experienced a mass mortality event, losing about $400 \mathrm{~kg}$ of full-sized fish (each weighing 700-800 g) during a week of cloudy and rainy days, when DO levels remained consistently low (DO concentration at night to early morning was about $0.1 \mathrm{mg} / \mathrm{L}$ ). The average minimum DO concentrations in integrated and commercial culture systems were lower than $1 \mathrm{mg} / \mathrm{L}$ (Fig. 5), confirming that both types of culture systems are prone to risk of 
DO depletion (Sriyasak et al. 2013). The reason for this is because these systems have high fish stocking densities and high nutrient inputs (Table 1) which stimulate high phytoplankton biomass.

Fish culture system and depth of pond had significant effects on TAN. In the bottom layer, TAN concentration was higher than surface water. This was likely due to the accumulation of nitrogen in the sediments (Hargreaves 1998; Kaggwa et al. 2010). Water de-stratification resulted in TAN concentration increasing at the surface layer; consequently, the diffusion of ammonia into the water column created a nutrient source to support the proliferation of phytoplankton (Hargreaves and Tucker 2004). TAN levels of integrated ponds were higher than commercial and subsistence systems. Ammonia of integrated and commercial culture systems, which had high feeding and fish stocking densities, were mainly from uneaten feed, feces, and fish excretes (Durborow et al. 1992; Gross et al. 1999). Average un-ionized ammonia concentration of all culture systems was lower than the proposed threshold toxicity levels for tilapia (less than $0.5 \mathrm{mg} / \mathrm{L}$ ) (Hargreaves and Tucker 2004). The level of un-ionized ammonia which have an impact on growth rate and can kill fish over a few days ranged between 0.2 and $0.6 \mathrm{mg} / \mathrm{L}$ (Durborow et al. 1992; El-Shebly and Gad 2011; Joel and Amajuoyi 2010), while the acute toxicity (24 h) of Nile tilapia fingerling is $7.4 \mathrm{mg} / \mathrm{L}$ (Benli and Koksal 2005). The suggested safe level for chronic exposure (over 2-3 week) to un-ionized ammonia concentration is lower than $0.05 \mathrm{mg} / \mathrm{L}$ (Lawson 1995; MacIntyre et al. 2008). Ammonia levels measured in this present study were therefore not considered toxic to the fish; and with continued good water management practices in place, it should not be a major problem in future.

The complex interactions among factors as found in this study, suggest that there should be value in adapting existing pond aquaculture models (e.g. Culberson and Piedrahita 1996) to explore in more detail the dynamic consequences of weather and climate in different culture systems on thermal and DO stratification.

\section{Conclusions}

Thermal water stratification results in low DO levels in fish ponds. De-stratification reduces DO near the surface and increases DO at the bottom layer. Stratification interventions like mixing water or using an aerator should be employed to reduce stratification, and further increase oxygen levels at the bottom of the pond. Integrated and commercial culture systems are more prone to risk from very low $\mathrm{DO}(<1 \mathrm{mg} / \mathrm{L})$, at around 02:00-06:00 $\mathrm{h}$, than the subsistence system. In both systems, organic matter inputs from feed and waste are high, resulting in high concentrations of phytoplankton; which consume a lot of oxygen at night. De-stratification also causes ammonia concentrations in the surface water layer to increase. Ammonia concentrations in all ponds observed in this study however, were lower than the toxic threshold levels for tilapia. This study found widespread evidence indicating that integrated and commercial culture systems are especially prone to low levels of DO concentrations at night; approaching or exceeding thresholds likely to impact fish health and survival. Pond management practices should be adjusted to reduce the risks of exceeding DO thresholds. In particular, fish farmers should: (1) take care to avoid over-feeding; manage water and sediments to prevent excessive accumulation of organic matter and waste at the bottom of ponds, which can influence other water quality parameters; and, (2) use aeration and mechanical mixing interventions at critical times to reduce stress on fish from low DO concentrations, and thus avoid risks of mass mortality events.

\section{Compliance with ethical standards}

Conflict of interest All authors declare that they have no conflicts of interest.

Open Access This article is distributed under the terms of the Creative Commons Attribution 4.0 International License (http:// creativecommons.org/licenses/by/4.0/), which permits unrestricted use, distribution, and reproduction in any medium, provided you give appropriate credit to the original author(s) and the source, provide a link to the Creative Commons license, and indicate if changes were made.

\section{References}

Abdel-Tawwab M (2012) Effects of dietary protein levels and rearing density on growth performance and stress response of Nile tilapia, Oreochromis niloticus (L.). Int Aquat Res 4:3 
Ahmed Z, Hisham A, Rahman A (2011) Ecomonitoring of climate impact on earthen pond water quality in El-Fayoum, Egypt. Int Res J Microbiol 2:442-454

APHA (1980) Standard method for the examination of water and wastewater. American public health association, Washington DC

Benli KA, Koksal G (2005) The acute toxicity of ammonia on tilapia (Oreochromis niloticus L.) larvae and fingerlings. Turk J Vet Anim Sci 29:339-344

Bhujel RC (2013) On-farm feed management practices for Nile tilapia (Oreochromis niloticus) in Thailand. In: Hasan MR, New MB (ed) On-farm feeding and feed management in aquaculture. FAO Fisheries and Aquaculture Technical Paper No. 583. Rome, FAO

Boyd CE, Romaire RP, Johnson E (1978) Predicting early morning dissolved oxygen concentration in channel catfish ponds. Trans Am Fish Soc 107:484-492. doi:10.1577/1548-8659(1978)107<484:PEMDOC>2.0.CO;2

Chainark S, Boyd CE (2010) Water and sediment quality, phytoplankton communities and channel catfish production in sodium nitrate-treated ponds. J Appl Aquac 22:171-185. doi:10.1080/10454431003736524

Chang WYB (1989) Estimates of hypolimnetic oxygen deficits in ponds. Aquac Fish Manag 20:167-172

Chang WYB, Ouyang H (1988) Dynamics of dissolved oxygen and vertical circulation in fish ponds. Aquaculture 74:263-276. doi:10.1016/0044-8486(88)90370-5

Chervinski J (1982) Environmental physiology of tilapias. In: Roger S, Pullin RSV, Lowe-McConell RH (ed) ICLARM Conference: topic in the Biology and Culture of Tilapias, Manila, September 1980. Worldfish, Bellagio, pp 119-128

Chitmanat C (2013) Nile tilapia disease. Chiangmai Vet J 11:75-86

Chowdhury AS, Hasan K, Alam K (2014) The use of an aeration system to prevent thermal stratification of water bodies: pond, lake and water supply reservoir. Appl Ecol Environ Sci 2:1-7. doi:10.12691/aees-2-1-1

Cloot A (1994) Effect of light intensity variations on the rate of photosynthesis of algae: a dynamical approach. Math Comput Model 19(9):23-33. doi:10.1016/0895-7177(94)90038-8

Culberson SD, Piedrahita RH (1996) Aquaculture pond ecosystem model: temperature and dissolved oxygen predictionmechanism and application. Ecol Model 89:231-258. doi:10.1016/0304-3800(95)00140-9

Diana SJ, Lin KC, Schneeberger JP (1991) Relationships among nutrient inputs, water nutrient concentrations, primary production, and yield of Oreochromis niloticus in ponds. Aquculture 92:323-341. doi:10.1016/0044-8486(91)90038-9

Diehl S (2002) Phytoplankton, light, and nutrients in a gradient of mixing depth: theory. Ecology 83:386-398. doi:10.1890/00129658(2002)083

DOF (2013) Report of tilapia production in the first quarter of 2013 [in Thai]. http://fishco.fisheries.go.th/fisheconomic/Doc/ fishnews_164.pdf. Accessed 10 Jan 2014

Durborow MR, Crosby MD, Brunson WM (1992) Ammonia in fish ponds. Southern Regional Aquaculture Center, Stoneville

Duy AT, Scharama J, Dam AV, Verreth AJ (2008) Effects of oxygen concentration and body weight on maximum feed intake, growth and hematological parameters of Nile tilapia, Oreochromis niloticus. Aquculture 275:152-162. doi:10.1016/j. aquaculture.2007.12.024

Egna HS, Boyd CE (1997) Dynamics of pond aquaculture. CRC Press, New York

El-Shebly AA, Gad MH (2011) Effect of chronic ammonia exposure on growth performance, serum growth hormone (GH) levels and gill histology of Nile tilapia (Oreochromis niloticus). J Microbiol Biotechnol Res 1(4):183-197

Emerson K, Russo RC, Lund RE, Thurston RV (1975) Aqueous ammonia equilibrium calculations: effect of pH and temperature. J Fish Res Board Can 32:2379-2383. doi:10.1139/f75-274

EPA (2013) Aquatic life ambient water quality criteria for ammonia-freshwater 2013. Office of Science and Technology, Washington, DC

Gandhi KT (2012) A study of water quality parameters to better manage our ponds or lakes. Int J Late Res Sci Technol 1:359-363

Gross A, Boyd CE, Wood CW (1999) Ammonia volatilization from freshwater fish ponds. J Environ Qual 28:793-797. doi:10. 2134/jeq1999.00472425002800030009x

Hargreaves J (1998) Nitrogen biogeochemistry of aquaculture ponds. Aquaculture 166:181-212. doi:10.1016/S00448486(98)00298-1

Hargreaves JA, Tucker CS (2004) Managing ammonia in fish ponds. Southern Regional Aquaculture Center, Stoneville

Janjai S, Wattan R (2011) Development of a model for the estimation of photosynthetically active radiation from geostationary satellite data in a tropical environment. Rem Sens Environ 115:1680-1693. doi:10.1016/j.rse.2011.02.026

Joel O, Amajuoyi CS (2010) Determination of the concentration of ammonia that could have lethal effect on fish pond. J Eng Appl Sci 5:1-4

Kaggwa R, Dam AA, Kipkemboi J, Denny P (2010) Evaluation of nitrogen cycling and fish production in seasonal ponds ('Fingerpond') in lake victoria wetlands, East Africa using a dynamic simulation model. Aquac Res 42:74-90. doi:10.1111/j. 1365-2109.2010.02563.x

Kepenyes J, Varadi L (1984) Aeration and oxygenation in aquaculture. In: FAO (ed) Inland aquaculture engineering. FAO, Rome

Klimaszyk P, Tomaz J (2007) Seasonal changeability of thermal and oxygen conditions in polyhumic lakes: Glodne Jeziorko III and Czarny Dol (northern Poland). Limnol Rev 7:199-203

Lawson TB (1995) Fundamentals of aquaculture engineering. Chapman \& Hall, New York

Litchman E, Klausmeier CA, Bossard P (2004) Phytoplankton nutrient competition under dynamic light regimes. Limnol Oceanogr 49((4, part 2)):1457-1462. doi:10.4319/lo.2004.49.4_part_2.1457

Little DC, Edwards P (2004) Impact of nutrition and season on pond culture performance of mono-sex and mixed-sex Nile tilapia (Oreochromis niloticus). Aquaculture 232:279-292. doi:10.1016/S0044-8486(03)00482-4

Losordo TM, Piedrahita RH (1991) Modelling temperature variation and thermal stratification in shallow aquaculture ponds. Ecol Model 54:189-226. doi:10.1016/0304-3800(91)90076-D

MacIntyre CM, Ellis T, North BP, Turnbull JF (2008) The influences of water quality on the welfare of farmed rainbow trout: a review. In: Branson EJ (ed) Fish welfare. Blackwell Publishing Ltd., Oxford 
Pandit NP, Nakamura M (2010) Effect of high temperature on survival, growth and feed conversion ratio of Nile Tilapia, Oreochromis niloticus. Our Nat 8:219-224. doi:10.3126/on.v8i1.4331

Pimolrat P, Whangchai N, Chitmanat C, Promya J, Lebel L (2013) Survey of climate-related risks to Tilapia pond farms in northern Thailand. Int J Geosci 4:54-59. doi:10.4236/ijg.2013.45B004

Randall DJ, Tsui TKN (2002) Ammonia toxicity in fish. Mar Pollut Bull 45:17-23. doi:10.1016/S0025-326X(02)00227-8

Romaire PR, Boyd EC (1979) Effects of solar radiation on the dynamics of dissolved oxygen in channel catfish ponds. Trans Am Fish Soc 108(5):473-478. doi:10.1577/1548-8659(1979)108<473:EOSROT $>2.0$

Smith DW, Piedrahita RH (1988) The relation between phytoplankton and dissolved oxygen in fish ponds. Aquculture 68:249-265. doi:10.1016/0044-8486(88)90357-2

Srisapoome P, Areechon N (2014) Serious disease outbreaks in Nile tilapia cultured in Thailand. http://www.rdi.ku.ac.th/ kasetresearch52/05-animal/prapansak_Nile/animal_00.html. Accessed 24 Dec 2014

Sriyasak P, Chitmanat C, Whangchai N, Promya J, Lebel L (2013) Effects of temperature upon water turnover in fish ponds in northern Thailand. Int J Geosci 4:18-23. doi:10.4236/ijg.2013.45B004

Sriyasak P, Whangchai N, Chitmanat C, Promya J, Lebel L (2014) Impacts of climate and season on water quality in aquaculture ponds. KKU Res J 19(5):743-751

Stefan HG, Hondzo M, Fang X, Eaton JG, McCormick JH (1996) Simulated long-term temperature and dissolved oxygen characteristics of lakes in the north-central United States and associated fish habitat limits. Limnol Oceanogr 41:1124-1135. doi:10.4319/lo.1996.41.5.1124

Szyper PJ, Lin CK (1990) Techniques for assessment of stratification and effects of mechanical mixing in tropical fish ponds. Aquac Eng 9:151-165. doi:10.1016/0144-8609(90)90002-H

Szyper PJ, Rosenfeld ZJ, Piedrahita HR, Giovannini P (1992) Diel cycles of planktonic respiration rates in briefly incubated water samples from a fertile earthen pond. Limnol Oceanogr 37(6):1193-1201. doi:10.4319/lo.1992.37.6.1193

Tadesse I, Green FB, Puhakka JA (2004) Seasonal and diurnal variations of temperature, $\mathrm{pH}$ and dissolved oxygen in advanced integrated wastewater pond systems treating tannery effluent. Water Res 38:645-654. doi:10.1016/j.watres.2003.10.006

Thai Meteorological Department (2012) The weather of Thailand. http://www.tmd.go.th/info/info.php?FileID=22. Accessed 9 Dec 2014

Thai Meteorological Department (2014) The weather data of Thailand. http://119.46.126.50/web/aws/aws_alphanumeric.asp. Accessed 12 Feb 2015 